DOI 10.18551/rjoas.2021-06.12

\title{
ELEMENTS OF RURAL OFF-FARM ECONOMY: EFFECTS OF OFF-FARM INCOME ON PRODUCTIVITY AND POVERTY STATUS OF RURAL MAIZE FARMING HOUSEHOLDS IN KADUNA STATE, NIGERIA
}

\author{
Alabi Olugbenga Omotayo \\ Department of Agricultural Economics, University of Abuja, Abuja, Nigeria \\ ORCID: 0000-0002-8390-9775 \\ Madaki Musa Janga, ORCID: 0000-0003-4983-0980 \\ David Hyelni Seth, ORCID: 0000-0003-2071-8821 \\ Department of Agricultural Economics and Extension, Federal University Gashua, \\ Gashua, Nigeria \\ Adewole Abiola Riike \\ Department of Agricultural Economics, University of Abuja, Abuja, Nigeria \\ ORCID: 0000-0003-2224-3145 \\ Ubandoma Garba Ahmed \\ Department of Agricultural-Economics and Extension Services, Faculty of Agriculture, \\ Ibrahim Badamasi Babangida University, Lapai, Nigeria \\ ORCID: 0000-0002-3250-1673 \\ Ogbole Esther Ojonugwa \\ Department of Agricultural Economics, University of Abuja, Abuja, Nigeria \\ ORCID: 0000-0002-2539-0610 \\ Omole Ebunlola Bosede \\ Basic Science Department, Federal College of Wildlife Management, \\ Forestry Research Institute of Nigeria, New Bussa, Nigeria \\ ORCID: 0000-0001-8493-4190 \\ Amkpa Rose Nimmo, ORCID: 0000-0002-8872-5238 \\ Olusola Bunmi Samuel, ORCID: 0000-0002-1530-4352 \\ Alabuja Funso Omolayo, ORCID: 0000-0002-7579-1041 \\ Department of Agricultural Economics, University of Abuja, Abuja, Nigeria \\ *E-mail: omotayoalabi@yahoo.com
}

\begin{abstract}
This study evaluated elements of rural off-farm economy: effects of off-farm income on productivity and poverty status of rural maize farming households in Kaduna State, Nigeria. This research study was designed specifically to achieve the following objectives: determine the socio-economic characteristics of rural maize farmers, determine the poverty status of rural maize farmers, determine the elasticity of production and return to scale of rural maize production, examine the effect of off-farm income on productivity of rural maize farmers, examine the effect of off-farm income on food security of rural maize farmers, and determine the constraints facing rural maize farming households. The econometric and statistical tools used to achieve stated objectives were; descriptive statistics, Foster, Greer and Thorbecke (FGT) poverty model, elasticity of production, return to scale, Probit model analysis, and Stochastic
\end{abstract}


production frontier model. Age distributions of rural maize farming households ( $\bar{x}=39.50$ years) shows that $83 \%$ of rural maize farming households were less than 50 years. About $69 \%$ of rural maize farming households had less than 10 people per household ( $\bar{x}=6$ people per household). The food poverty line was 4,210.16 Naira (8.77 USD). Poverty incidence $\left(P_{0}\right)$, poverty depth $\left(P_{1}\right)$ and poverty severity $\left(P_{2}\right)$ of rural maize farming households were $0.517,0.216$ and 0.221 respectively. Determinants of productivity of rural maize farming households are farm size $(P<0.05)$, seed input $(P<0.05)$, fertilizer input $(P<0.05)$, chemical input $(P<0.10)$, and labour input $(P<0.05)$. In the inefficiency model, level of education $(P<$ $0.05)$, marital status $(P, 0.10)$, off-farm income $(P<0.05)$, access to extension agents $(P<0.05)$ and access to credit $(P, 0.10)$ statistically and significantly reduces the probability of rural maize farming households of being food poor. Factors that statistically and significantly reduces food poverty status among rural maize farming households were gender $(P<0.05)$, educational level $(P<0.10)$, extension contact $(P<0.01)$ and off-farm income $(P<0.01)$. The retained production constraints facing rural maize farming households in the principal component analysis are lack of credit facilities, lack of fertilizers, lack of improved seeds, bad road infrastructures and lack of extension services.

\section{KEY WORDS}

Off-farm income, productivity, poverty status, rural maize farmers, Kaduna State, Nigeria.

Rural livelihoods income comes from farm, non-farm and off-farm sources. Rural farming households now diversified into off-farm and/or non-farm activities as a surviving strategy (Astatike and Gazuma, 2019). In sub-Saharan countries, off-farm income constitutes about 35$50 \%$ of income for rural farming households (Haggblade, Hazell and Reardon, 2010). Off-farm activities can be defined as activities performed by rural farmers away from his or her own farms, this involves activities performed in other peoples farms plus activities performed outside agricultural sector (Non-Farm). Non-farm activities can be defined as activities performed by rural farmers outside agricultural sector (Barrett, Reardon and Webb, 2001; Haggblade, Hazell and Reardon, 2007).

Rural off-farm economy is of great importance for rural economy because it generates employment, provides both production linkages and substantial rural income for rural households. Off-farm income relaxes the budget constraints of rural farming households. Offfarm activities improve the standard of living, livelihood security of rural farmers and absorb surplus agricultural labour input. In sub-Saharan countries, rural poverty is the major issue, majority of their population live in rural areas and basically depend on agriculture. Off-farm income would significantly add to income of rural farming households and reduce rural poverty (lqbal et al, 2017). Poverty according to Folorunso, Gama and Ademiluyi (2018) can be defined as rural farmers' inability to adequately meet the basic human necessities such as food, clothing, shelter and medicare. According to Obayelu and Orosile (2015), food poverty is the inability of rural farming households to afford, or have access to quality food in sufficient quantity to make up a healthy diet. Food poverty among rural farmers is the result of failure of rural livelihood to guarantee access to sufficient food at the household level. Livelihood means making a living, the various activities and resources that allow people to live. Rural farming households that are food poor are also food insecure. Food insecurity and poverty are more prominent in rural areas of Nigeria. Despite the fact that rural farmers are involved in farming activities, their income remains low.

Agriculture has the potentials of reducing rural poverty and promoting economic development in Africa (Rufai, Salman and Salawu, 2018). David (2010) explained the need to improve productivity in sub-Saharan countries for it to reduce poverty and have higher impact on aggregate economic indicators. The low productivity of agriculture in sub-Saharan Africa has been attributed to the fact that the sector are made up of small-scale farmers who use 
rudimentary production technique and the increasing out-migration of men from rural areas and their participation in off-farm activities and left agriculture more in the hands of rural women (Lastarria-Corhiel, 2006). Low productivity among rural farmers can be further attributed to poor access to farm inputs, new technologies, credit facilities and extension services. Knowledge of efficiency of resource use among rural farmers is also vital in agricultural productivity (Edet and Falake, 2006). Productivity growth and efficiency of farm resources are core issues of sustainable agricultural production of small-scale rural farming activities.

The broad objective evaluated elements of rural off-farm economy: effects of off-farm income on productivity and poverty status of rural maize farming households in Kaduna State, Nigeria. This study was designed specifically to achieve the following objectives:

(i) Identify the socio-economic characteristics of rural maize farmers;

(ii) Determine the poverty status of rural maize farmers;

(iii) Determine the elasticity of production and return to scale of rural maize production;

(iv) Examine the effect of off-farm income on productivity of rural maize farmers;

(v) Examine the effect of off-farm income on poverty status of rural maize farmers, and

(vi) Determine the constraints facing rural maize farming households in the study area.

\section{METHODS OF RESEARCH}

This research study will be conducted in Kaduna State. The State lies between Latitudes $10^{\circ} 20^{\circ} \mathrm{N}$ and Longitudes $7^{0} 45^{\prime} \mathrm{E}$. Kaduna State has land mass of $46,053 \mathrm{Km}^{2}$ with population of $6,113,503$ people (NPC, 2006). The inhabitants of the state are farmers; crops grown include maize, millet, groundnuts, cowpea, rice, yam, cassava, ginger, tomatoes, and sorghum. They also reared animals like goats, sheep, poultry birds, and cattle. Primary sources of data were used. Data were collected with the aid of well-structured questionnaire. Data were subjected to validity and reliability test. Multi-stage sampling technique was used to selected target maize farming households. First, second and third stages involves the simple random selection of Kaduna North, 5 wards, 5 villages respectively using ballot-box, raffle draw method. The fourth stage involves selecting of 100 maize farming households following Yamane (1967) formula for estimating sample size as stated thus:

$$
\mathrm{n}=\frac{\mathrm{N}}{\left(1+\mathrm{N}(\mathrm{e})^{2}\right.}=100
$$

Where: $n$ = Sample Size (Units), N = Sample Frame (Units), e = Level of Precision (5\%).

Data obtained from the field were subjected to statistical and econometrics analysis.

Descriptive Statistics includes frequency distributions, mean, and percentages. This was used to have a summary statistics of data collected from maize farmers. This was used to identify the socio-economic characteristics as stated in specific objective one.

The FGT model is specified thus:

$$
P_{\alpha i}=\frac{1}{N} \sum_{\mathrm{i}=1}^{\mathrm{q}}\left[\frac{\mathrm{Z}-\mathrm{Y}_{\mathrm{i}}}{\mathrm{Z}}\right]^{\alpha}
$$

Where: $P_{a i}=$ FGT Poverty Index for the $i^{\text {th }}$ Sub-Groups, $N=$ Total Number of Maize Farmers in the Population, $Y_{i}=$ Per Capital Expenditure of $i^{\text {th }}$ Maize Farmers, $Z=$ The Poverty Line, $q=$ The Number of the Sampled Maize Farmers in the Population below the Poverty Line, $\alpha=$ The Degree of Aversion and take on the Value of $0,1,2$.

The headcount ratio measures the incidence of poverty and it is obtained as: 


$$
\begin{aligned}
\mathrm{FGT}_{\alpha} & =\frac{1}{N} \sum_{\mathrm{i}=1}^{\mathrm{q}}\left[\frac{\mathrm{Z}-\mathrm{Y}_{\mathrm{i}}}{\mathrm{Z}}\right]^{\alpha}=P_{0}=\frac{\mathrm{H}}{\mathrm{N}} \\
\text { when }(\alpha=0) & \\
\mathrm{Pa} & =\mathrm{P}=\text { Poverty Incidence or Head Count Ratio }
\end{aligned}
$$

Where: $\mathrm{H}=$ Number of Individuals below Poverty Line, $\mathrm{N}=$ The Number of Individuals in Reference Population.

Poverty Gap: When $\alpha$ is equal to 1, equation becomes.

$$
\mathrm{P}_{1}=\frac{1}{\mathrm{~N}} \sum_{\mathrm{i}-1}^{\mathrm{q}}\left[\frac{\mathrm{z}-\mathrm{y}_{\mathrm{i}}}{\mathrm{z}}\right]^{1}
$$

Square Poverty Gap: When $\alpha$ is equal to 2, the equation becomes.

$$
\mathrm{P}_{2}=\frac{1}{\mathrm{~N}} \sum_{\mathrm{i}-1}^{\mathrm{q}}\left[\frac{\mathrm{Z}-\mathrm{Y}_{\mathrm{i}}}{Z}\right]^{2}
$$

About 2/3 of mean per capital household expenditure MPCHE was estimated as the poverty line, the extreme poor (those spending $<1 / 3$ of MPCHE, moderately poor (those spending $<2 / 3$ of MPCHE and the non-poor (those spending $>2 / 3$ of MPCHE).

This was used to determine the poverty status of maize farmers as stated in specific objective two (ii).

The stochastic production frontier model is stated thus:

$$
\begin{aligned}
& Y_{i}=\left(X_{i}, \beta_{i}\right) e^{v_{i}-u_{i}} \\
& l_{n} Y=\propto_{0}+\beta_{1} l_{n} X_{1}+\beta_{2} l_{n} X_{2}+\beta_{3} l_{n} X_{3}+\beta_{4} l_{n} X_{4}+\beta_{5} l_{n} X_{5}+V_{i}-U_{i}
\end{aligned}
$$

Where:

$Y_{i}=$ Output of Maize $(\mathrm{Kg})$;

$\mathrm{X}_{i}=$ Vector of Variable Inputs;

$\beta_{i}=$ Vector of Estimated Parameters;

$\mathrm{V}_{\mathrm{i}}=$ Error Term, Random Variation in Output;

$U_{i}=$ Error Term due to Technical Inefficiency;

$\mathrm{X}_{1}=$ Farm Size (Hectares);

$X_{2}=$ Improved Seed Input $(\mathrm{Kg})$;

$\mathrm{X}_{3}=$ Fertilizer Input $(\mathrm{Kg})$;

$\mathrm{X}_{4}=$ Chemical Input (Litre);

$\mathrm{X}_{5}=$ Labour Input (Mandays).

$$
U_{i}=\delta_{0}+\delta_{1} Z_{1}+\delta_{2} Z_{2}+\delta_{3} Z_{3}+\delta_{4} Z_{4}+\delta_{5} Z_{5}+\delta_{6} Z_{6}+\delta_{7} Z_{7}+\delta_{8} Z_{8}
$$

Where:

$\mathrm{U}_{\mathrm{i}}=$ Error Term associated with Technical Inefficiency;

$Z_{1}=$ Gender (1, Male; 0, Otherwise);

$Z_{2}=$ Age(Years);

$Z_{3}=$ Marital Status (1, Married; 0, Otherwise);

$Z_{4}=$ Level of Education (0, Non-Formal, 1, Primary, 2, Secondary, 3, Tertiary);

$Z_{5}=$ Household Size (Number);

$Z_{6}=$ Off-Farm Income (Naira); 
$Z_{7}=$ Access to Extension Officers or Agents (Number of Meetings/Week);

$\mathrm{Z}_{8}=$ Access to Credit (1, Access; 0, Otherwise);

$\delta_{0}=$ Constant Term;

$\delta_{1}-\delta_{8}=$ Parameters to be estimated.

This was to examine the effect of off-farm income on productivity of maize farmers as stated in specific objective four (iv).

Return to scale of the farm operations can either be increasing, decreasing, or constant return to scale base on the value.

$$
R T S=\sum E P I_{S}
$$

Where: RTS = Returns to Scale, $E P I_{S}=$ Elasticity of Production Inputs (Units).

This was used to determine elasticity of production and return to scale as stated in specific objective three (iii).

The Probit Model is stated thus:

$$
\begin{aligned}
Y_{i} & =b_{0}+b_{1} X_{1}+b_{2} X_{2}+b_{3} X_{3}+b_{4} X_{4}+b_{5} X_{5}+b_{6} X_{6}+e_{i} \\
Y_{i} & =b_{0}+\sum_{i=1}^{6} b_{i} X_{i}+e_{i}
\end{aligned}
$$

Where:

$Y_{i}=$ Dichotomous Response Variable (1, Poor; 0, Non-Poor);

$X_{1}=$ Age (Years);

$X_{2}=$ Gender Dummy (1, Male; 0, Female);

$X_{3}=$ Educational Level (1, Formal Education; 0, Otherwise);

$X_{4}=$ Household Size (Number of Persons);

$X_{5}=$ Extension Contact (1, Contact; 0, Otherwise);

$X_{6}=$ Off-Farm Income (Naira);

$\mathrm{b}_{0}=$ Constant Term;

$b_{1}-b_{6}=$ Regression Coefficients;

$e_{i}=$ Error Term.

This was used to examine effect of off-farm income on poverty status of maize farmers as stated in achieve specific objective five (v).

The constraints facing rural maize farmers as stated in specific objective six (vi) were subjected to principal component analysis. Principal Component Analysis transformed many interrelated variables into few unrelated variables.

\section{RESULTS AND DISCUSSION}

The socio-economic characteristics of rural maize farmers are presented in Table 1. About $83 \%$ of rural maize farmers are less than 50 years of age. This implies that rural maize farmers were young, energetic, and resourceful in their active age. The mean age of rural maize farmers was 39 years. Also, $67 \%$ of rural maize farmers were male, while $33 \%$ were female. In terms of marital status, $37 \%$ of sampled rural maize farming households were married, while $47 \%$ were single. In addition, $89 \%$ of sampled rural maize farming households had formal education, this include: primary (30\%); secondary (40\%); tertiary (19\%). Also, $11 \%$ of sampled rural maize farming households had no formal education. This implies that rural maize farming households have the knowledge base and can adopt innovations and research findings easily. The household sizes were large with an average of 7 people per household. About $69 \%$ of 
sampled rural maize farming households had less than 10 people per household. This study is in line with findings of Astatike and Gazuma (2019) who reported mean age of 44 years and average household size of 5 people per household among farming households in Southern Ethiopia.

Table 1 - Socio-Economic Profiles of Rural Maize Farming Households

\begin{tabular}{|c|c|c|c|}
\hline Variables & Frequency & Percentage & Mean \\
\hline Age (Years) & & & \\
\hline $21-30$ & 22 & 22.00 & 39.50 \\
\hline $31-40$ & 33 & 33.00 & \\
\hline $41-50$ & 28 & 28.00 & \\
\hline $51-60$ & 17 & 17.00 & \\
\hline Gender & & & \\
\hline Male & 67 & 67.00 & \\
\hline Female & 33 & 33.00 & \\
\hline Marital Status & & & \\
\hline Single & 47 & 47.00 & \\
\hline Married & 37 & 37.00 & \\
\hline Divorced & 19 & 19.00 & \\
\hline Widow/Widower & 03 & 03.00 & \\
\hline Educational Status & & & \\
\hline Primary & 30 & 30.00 & \\
\hline Secondary & 40 & 40.00 & \\
\hline Tertiary & 19 & 19.00 & \\
\hline Non-Formal & 11 & 11.00 & \\
\hline $\begin{array}{l}\text { Household Size } \\
\text { (Units) }\end{array}$ & & & \\
\hline $1-5$ & 38 & 38.00 & 7.65 \\
\hline $6-10$ & 31 & 31.00 & \\
\hline $11-15$ & 31 & 31.00 & \\
\hline Total & 100.00 & 100.00 & \\
\hline
\end{tabular}

Source: Field Survey (2021).

Table 2 - Poverty Status of Rural Maize Farming Households

\begin{tabular}{|l|l|l|l|}
\hline Poverty Status & \multicolumn{3}{|l|}{ Per Capital Households Expenditure (Naira) } \\
\cline { 2 - 4 } & Non-Poor & Poor & Total \\
\hline Mean & $9,804.12$ & $1,671.43$ & $6,315.24$ \\
\hline Food Poverty Line & $=4,210.16$ Naira & \\
FGT & & \\
Poverty Incidence $\left(\mathrm{P}_{0}\right)$ & $=0.517$ & \\
Poverty Depth $\left(\mathrm{P}_{1}\right)$ & $=0.261$ & \\
Poverty Severity $\left(\mathrm{P}_{2}\right)$ & $=0.221$ & \\
\hline
\end{tabular}

Source: Field Survey (2021), 1 USD $=480$ Naira.

The food poverty profiles of rural maize farming households are presented in Table 2 . Based on the food poverty line, households were classified into food poor households and food non-poor households. Two-third of the mean per capital households' food expenditure of the sampled rural maize farming households was used as poverty line in the same method as used by Omonona et al (2007). The poverty line was 4, 210.16 Naira (8.77 USD), this shows the minimum cost of eliminating poverty, the amount that could be transferred to the poor to bring their expenditure up to poverty line. The food poverty incidence $\left(\mathrm{P}_{0}\right)$ was 0.517 , this implies that $51.70 \%$ of the rural maize farming households were poor and $49.30 \%$ were non-poor. The poverty gap index $\left(\mathrm{P}_{1}\right)$ usually referred to as the depth of an average poor person from the poverty line was 0.261 , this implies that $26.1 \%$ of rural maize farming households were poor. The poverty severity $\left(\mathrm{P}_{2}\right)$ which measures the distance of each poor person to one another was found to be 0.221 . This implies that among the rural maize farming $22.1 \%$ were severely poor. The mean per capital expenditure was 9,804.12 for non-poor rural maize farming households and 1,671.43 for poor rural maize farming households. This result is similar to results of 
Obayelu and Orosile (2015) who reported poverty incidence $\left(\mathrm{P}_{0}\right)$ of 0.45 , poverty depth $\left(\mathrm{P}_{1}\right)$ of 0.25 and poverty severity of $\left(\mathrm{P}_{2}\right)$ of 0.16 among 150 households in Ekiti State, Nigeria.

Estimates of Stochastic production frontier model and technical efficiency scores are presented in Table 3 and 4. The coefficient of gamma $(\mathrm{Y})$ of 0.69017 is very close to one, and is statistically and significantly different from zero at $(P<0.01)$, also Lambda $(\lambda)$ of 1.3140 is greater than one and statistically significant at $(P<0.01)$. This suggests the presence technical inefficiency among the rural maize farmers. The results of the estimated parameters showed that all the coefficients of the technical components conform with a priori expectations of having positive signs. The statistically and significant physical variables included in the technical efficiency components are: farm size $(P<0.10)$, seed input $(P<0.05)$, fertilizer input $(P<0.05)$, chemical input $(P<0.05)$, and labour input $(P<0.05)$. Seed input is statistically and significantly contributes more to yields of Maize than other agricultural inputs included in the model. A $1 \%$ increase in improved seed inputs will leads to $29.04 \%$ improvement in maize yields. Maize producers who used improved seeds per hectare performed better. These results is in line with findings of Houngue and Nonvide (2020) who showed that improved seed inputs significantly contributes $19.1 \%$ to rice production. These results also conform to findings of Oppong et al (2014) and Shabu (2013) who reported that seed inputs contributes significantly about $25 \%$ of maize and rice production in Ghana and Nigeria respectively. Chemical input contributes the least to rural maize production among farming households. A $1 \%$ increase if chemical input will result in a $5.74 \%$ improvement in maize yield. This in line with findings of Houngue and Nonvide (2020) who reported $4.8 \%$ increase in rice yield from $1 \%$ increase in herbicide input. These results are in line with those obtained by Oppong et al (2014) and Ogundari (2008). Table 3 also presents the results of the technical inefficiency model of rural maize production. The statistical and significant variables in the inefficiency model are gender $(P<0.05)$, age $(P<0.05)$, marital status $(P<0.10)$, level of education $(P<0.05)$, household size $(P<0.05)$, off-farm income $(P<$ $0.05)$, access to extension agent $(P<0.05)$ and access to credit $(P<0.10)$. The coefficient of age is positive and significant, this implies that as rural maize farmers get older they are less efficient than younger ones, in addition they are less receptive to research findings, new innovations and technical changes in maize production that influence efficiency. The coefficient associated with level of education is negative and significant. This means level of education contributes to the reduction of inefficiency in maize production. This result is in line with previous work of Elias et al (2017) and Yabi (2009). Access to credit has negative and significant coefficient, this implies that access to credit facilities reduces the inefficiency of maize production. Access to credit facilities enables rural farmers to purchase farm inputs in time and avoid delays in farming activities (Houngue and Nonvide, 2020; Mdemu et al, 2017). Off-farm income has negative and significant coefficient. This means that off-farm income significantly increase technical efficiency and reduces inefficiency in maize production. This result is in line with previous work of Astatike and Gazuma (2019) who reported that off-farm activities significantly influence total income of households in Southern Ethiopia. The estimated technical efficiency score varies from $21 \%$ to $99 \%$ with an average of $68.3 \%$ (Table 4 ). About $7 \%$ of rural maize farmers have their technical inefficiencies scores less than $50 \%$. This means there are opportunities to increase rural maize production by adopting new innovations, research findings and better farm practices. These results are similar to previous studies carried out by Houngue and Nonvide (2020), Dhungana et al (2004), Singbo and Lansink (2010), Kadiri et al (2014) and Ouedraogo (2015).

The coefficients of the physical variables included in the technical efficiency component of the stochastic production frontier model are the elasticities of production. This implies that the elasticities of production of farm size, seed input, fertilizer input, chemical input and labour input are $0.1987,0.2904,0.2231,0.0574$, and 0.2801 respectively. The summation of elasticities of production gives the return to scale. The return to scale of rural maize production is 1.0497. This implies an increasing return to scale because the value of return to scale is greater than one. 
This is similar to previous result of Tesema, Kebede and Shumeta (2019) who obtained in their results the return to scale of 1.0341 in smallholder maize production in Ethiopia.

Table 3 - Stochastic Production Frontier Model for the Rural Maize Production

\begin{tabular}{|c|c|c|c|}
\hline Variables & Coefficient & Standard Error & Z-Score \\
\hline Farm Size $\left(X_{1}\right)$ & $0.1987^{\star}$ & 0.1013 & 1.96 \\
\hline Improved Seed Input $\left(X_{2}\right)$ & $0.2904^{\star *}$ & 0.1143 & 2.54 \\
\hline Fertilizer Input $\left(\mathrm{X}_{3}\right)$ & $0.2231^{\star *}$ & 0.0823 & 2.71 \\
\hline Chemical Input $\left(\mathrm{X}_{4}\right)$ & $0.0574^{\star *}$ & 0.0244 & 2.35 \\
\hline Labour Input $\left(X_{5}\right)$ & $0.2801^{* *}$ & 0.1120 & 2.50 \\
\hline Constant & $2.1430^{*}$ & 1.0823 & 1.98 \\
\hline \multicolumn{4}{|l|}{ Inefficiency Model } \\
\hline Gender $\left(\mathrm{Z}_{1}\right)$ & $0.0302^{* *}$ & 0.0107 & 2.82 \\
\hline Age $\left(Z_{2}\right)$ & $0.0170^{\star *}$ & 0.0070 & 2.42 \\
\hline Marital Status $\left(\mathrm{Z}_{3}\right)$ & $-0.3402^{*}$ & 0.1718 & -1.98 \\
\hline Level of Education $\left(\mathrm{Z}_{4}\right)$ & $-0.5629^{* *}$ & 0.2108 & -2.67 \\
\hline Household Size $\left(Z_{5}\right)$ & $-0.4210^{* *}$ & -0.1625 & -2.59 \\
\hline Off-Farm Income $\left(\mathrm{Z}_{6}\right)$ & $-0.3725^{\star *}$ & 0.1258 & -2.96 \\
\hline Access to Extension Agent $\left(\mathrm{Z}_{7}\right)$ & $-0.4221^{\star *}$ & 0.1892 & -2.23 \\
\hline Access to Credit $\left(\mathrm{Z}_{8}\right)$ & $-0.3671^{*}$ & 0.1872 & -1.96 \\
\hline Return to Scale & 1.0497 & & \\
\hline \multicolumn{4}{|l|}{ Lambda $(\lambda) 1.3140$} \\
\hline \multicolumn{4}{|l|}{ Sigma- Squared $0.2702^{\star \star *}$} \\
\hline Gamma (ү). 0.69017*** & & & \\
\hline
\end{tabular}

Source: Field Survey (2021).

*- Significant at $10 \%$ Probability Level,

*** Significant at 5\%Probability Level, and

*** Significant at $1 \%$ Probability Level.

Table 4 - Summary Statistics of Technical Efficiency

\begin{tabular}{|l|l|l|l|}
\hline Efficiency Score & Freq. & Percent & Cumulative \\
\hline $0.21-0.50$ & 07 & 07.00 & 07.00 \\
$0.51-0.60$ & 25 & 25.00 & 32.00 \\
$0.61-0.70$ & 15 & 15.00 & 47.00 \\
$0.71-0.80$ & 27 & 27.00 & 74.00 \\
$0.81-0.90$ & 19 & 19.00 & 93.00 \\
$0.91-0.99$ & 07 & 07.00 & 100.00 \\
\hline Total & 100 & 100 & \\
\hline Mean & 0.683 & & \\
Standard Deviation & 0.1717 & & \\
Minimum & 0.215 & & \\
Maximum & 0.923 & & \\
\hline
\end{tabular}

Source: Data Analysis (2021).

The determinants of rural maize farming households food poverty status using the dichotomous Probit regression model was presented in Table 5. The Log-Likelihood value was 101.211 ( $P<0.01$ ) implies that the model has a good fit. The statistically and significant explanatory variables included in the Probit model are age $(P<0.01)$, gender $(P<0.05)$, educational level $(P<0.10)$, household size $(P<0.05)$, extension contact $(P<0.01)$ and offfarm income $(P<0.01)$. The coefficients of age and household size are positive and statistically significant in influencing food poverty status of rural maize farming households. This means as rural farming households head becomes older in age and the number of people per households increases, then the probability of being food poor increases by $1,27 \%$ and $26.37 \%$ respectively. This result is in line with previous studies of Obayelu and Orosile (2015) who reported that household food poverty increased with increase in household size and dependency ratio, which is the proportion of non-working members. The negative and statistically significant coefficient $(-0.112)$ of educational level of the rural maize farming households head indicates that the probability of being food poor reduced by $20.31 \%$ with the household head having the highest 
educational attainment of tertiary education. Off-farm income has statistically and significant effect on food poverty status of rural maize farming households. Off-farm income has negative and statistically significant coefficient of -0.230 , this implies that as off-farm income increases by $1 \%$ the probability of rural maize farming households being food poor reduced by $32.14 \%$. According to Astatike and Gazuma (2019), the total annual income of households who participated in off-farm activities is found to be higher than that of non-participants, this is because households who participated in off-farm activities diversify their income sources which obviously increase their total income. Farming households with off-farm activities have higher overall income than farming households with only single source of income. According to Babatunde and Qaim (2010) households with off-farm income seems to have better access to more nutritious food, which is also reflected in significantly higher level of micronutrients consumption. Also, off-farm income increase the probability of households being food secure.

Table 5 - Maximum Likelihood Estimates of Probit Regression Model

\begin{tabular}{|l|l|l|l|}
\hline Variables & Coefficient & Standard Error & Marginal Effects \\
\hline Age $\left(\mathrm{X}_{1}\right)$ & $0.113^{* * *}$ & 0.032 & 0.0127 \\
Gender $\left(\mathrm{X}_{2}\right)$ & $-0.136^{* *}$ & -0.340 & -0.1180 \\
Educational Level $\left(\mathrm{X}_{3}\right)$ & $-0.112^{*}$ & -0.059 & -0.2031 \\
Household Size $\left(\mathrm{X}_{4}\right)$ & $0.139^{* *}$ & 0.052 & 0.2637 \\
Extension Contact $\left(\mathrm{X}_{5}\right)$ & $-0.151^{* * *}$ & -0.043 & -0.2193 \\
Off-Farm Income $\left(\mathrm{X}_{6}\right)$ & $-0.230^{* * *}$ & -0.066 & -0.3216 \\
Constant & $0.126^{*}$ & & \\
LR Chi Square & $74.51^{* * *}$ & & \\
Pseudo - R & 0.7201 & \\
Log-Likelihood & -101.211 & & \\
Prob $>\mathrm{Chi}^{2}$ & 0.0000 & & \\
\hline
\end{tabular}

Source: Field Survey (2021).

*** - Significant at $P<0.01,{ }^{* *}$ - Significant at $P<0.05$, * Significant at $P<0.10$.

Table 6 - Results of the Principal Component Analysis of Constraints Facing Rural Maize Farmers

\begin{tabular}{|l|l|l|l|l|}
\hline Component & Eigen-Value & Difference & Proportion & Cumulative \\
\hline Lack of Credit Facilities & 2.1672 & 0.9862 & 0.1562 & 0.1562 \\
Lack of Fertilizers & 2.0341 & 0.8405 & 0.1935 & 0.3497 \\
Lack of Improved Seeds & 2.0021 & 0.8293 & 0.1897 & 0.5394 \\
Bad Road Infrastructures & 1.9821 & 0.7989 & 0.1569 & 0.6963 \\
Lack of Extension Services & 1.8762 & 0.8976 & 0.1509 & 0.8472 \\
\hline Bartlett Test of Sphericity & & & \\
Chi-Square & 520.270 & & \\
Rho & 1.0000 & & \\
KMO & 0.5962 & & \\
\hline
\end{tabular}

Source: Field Survey (2021).

* - Significant at 10\%Probability Level,

** - Significant at 5\%Probability Level, and

*** - Significant at 1\% Probability Level.

The production constraints facing rural maize farming households were subjected to principal component analysis (Table 6). Principal component analysis is an analytical tool that can translate many interrelated production variable into few unrelated ones. The retained production constraints had Eigen-value greater than one and they are lack of credit facilities (2.1672), lack of fertilizers (2.0341), lack of improved seeds (2.0021), bad road infrastructures (1.9821) and lack extension agents (1.8762). The retained components explained $84.72 \%$ of all production constraints included in the model. The Chi-square value of 520.270 was significant at $(P<0.01)$. 


\section{CONCLUSION}

Based on the findings of this research study, it can be concluded that rural maize farmers are young, active, energetic and resourceful with mean age of 39 years. The households' sizes were large with average of 7 people per household. The food poverty line was 4, 210.16 Naira (8,58 USD). Food poverty incidence $\left(P_{0}\right)$, poverty depth $\left(P_{1}\right)$, and poverty severity $\left(P_{3}\right)$ of rural maize farming households were $0.517,0.261$ and 0.221 respectively. Factors statistically and significantly influencing technical efficiency of rural maize production were farm size, seed input, fertilizer input, chemical input and labour input. In the inefficiency component, gender, age, marital status, level of education, household size, off-farm income, access to extension agent and access to credit facilities were statistically significant. The mean technical efficiency of rural maize production was 0.683 . Determinants of food poverty status among rural maize farming households were age, gender, educational level, household size, extension contact and off-farm income. Production constraints facing rural maize farming households were lack of credit facilities, lack of fertilizers, lack of improved seeds, bad road infrastructures and lack of extension services.

\section{RECOMMENDATIONS}

Based on the results of this research study, the following recommendations were made:

- Production inputs such as improved seeds, fertilizers, should be made available to rural maize farmers to increase output of maize production and reduce food poverty;

- Credit facilities should be provided to rural maize farmers at low interest rate to enable then procure necessary farm inputs at appropriate time;

- Rural maize farmers are advice to diversify into off -farm activities to increase income and reduce food poverty;

- Extension officers should be employed to train rural maize farmers on new methods of farming and improved technologies.

\section{REFERENCES}

1. Astatike, A.A and Gazuma, E. G (2019). The Impact of Off-Farm Activities on Rural Household Income in Wolaita Zone, Southern Ethiopia. Journal of World Economic Research, 8 (1): 8 - 16.

2. Babatunde, R.O and Qaim, M (2010). Impact of Off-Farm Income on Food Security and Nutrition in Nigeria. Poster Presented at the Joint African Association of Agricultural Economists (AAAE) and 48th Agricultural Association of South Africa (AEASA) Conference, Cape Town, South Africa, September 19 - 23, 2010.

3. Barrett, C.B., Reardon, $T$ and Webb, $P$ (2001). Non-Farm Income Diversification and Household Livelihood Strategies in Rural Africa: Concepts, Dynamics, and Policy Implications Food Policy, 26 (2): 315 -331.

4. David, S (2010). The Rural Non-Farm Economy, Livelihood Strategies and Household Welfare. African Journal of Agricultural Research, 4 (1): 82 - 109.

5. Dhungana, B.R., Nuthall, P.L and Nartea, G.V (2004). Measuring the Economic Inefficiency of Nepalese Rice Farms using Data Envelope Analysis. The Australian Journal of Agricultural and Resource Economics, 48 (2): 347 - 369.

6. Edet, J.U and Falake, O. (2006). Resource-Use Efficiency and Productivity among Farmers in Nigeria. Journal of Agricultural and Social Sciences, 2 (4): $264-268$. 
7. Elias, S., Warju, A and Mathewos, N (2017). Technical Efficiency of Smallholder Coffee Farmers in Gedeo Zone, Southern Ethiopia: A Stochastic Frontier Approach. Agricultural Science Research Journal, 7 (4): 147 - 153.

8. Folorunso, S.T., Gama, E.N and Ademiluyi, I.O (2018). Analysis of Food Security and Poverty Status among Agro-Pastoralists in Barkin-Ladi Local Government Area, Plateau State, Nigeria. FUDMA Journal of Agriculture and Agricultural Technology, 4 (1): $32-46$.

9. Haggblade, S., Hazell, $P$ and Reardon, $T$ (2007). Transforming the Rural Non-Farm Economy: Opportunity and Threats in the Developing World. The Johns Hopkins University Press, Baltimore.

10. Haggblade, S., Hazell, P and Reardon, T (2010). The Rural Non-Farm Economy: Prospect for Growth and Poverty Reduction. World Development, 38 (10): 1429 - 1441, Elsevier Ltd.

11. Houngue, V and Nonvide, G.M.A (2020). Estimation and Determinants of Efficiency among Rice Farmers in Benin. Cogent Food and Agriculture, 6: 1, 1819004.

12. Iqbal, M. A., Abbas, A., Ullah, R., Ahmed, U.I., Sher, A and Akhtar, S (2017). Effects of NonFarm Income on Poverty and Income Inequality: Farm Households Evidence from Punjab Province Pakistan. Sarhad Journal of Agriculture, 34 (2): 233 - 239.

13. Kadiri, F.A., Eze, C.C., Orebiyi, J.S., Lemchi, J.I., Ohajianya, D.O and Nwaiwu, I.U (2014). Technical Efficiency in Paddy Rice Production in Niger Delta Region of Nigeria. Global Journal of Agricultural Research, 2 (2): 33 - 43.

14. Lastarria-Corhiel, S (2006). Feminization of Agriculture: Trends and Driving Forces. Background Paper for the World Development Report 2008, November 2006.

15. NPC (2006). National Population Commission of Nigeria, Population Census, 2006.

16. Obayelu, O.A and Orosile, O. R (2015). Rural Livelihood and Food Poverty in Ekiti State Nigeria. Journal of Agriculture and Environment for International Development, 109 (2): $307-323$.

17. Oppong,B.A., Onumah, E.E and Asuming-Brempong, S (2014). Sthoastic Frontier Modelling of Maize Production in Brong-Ahafo Region of Ghana. Agris On-line Papers in Economics and Sustainable Development, 6(14): $78-85$.

18. Omonona, B.T and Agoi, G.A (2007). An Analysis of Food Security Situation among Nigeria Households: Evidence from Lagos State, Nigeria. Journal of Central European Agriculture, 8(3): $397-406$.

19. Ouedraogo, S (2015). Technical and Economic Efficiency of Rice Production on the Irrigated Plain of Bagre (Burkina Faso), A Stochastic Frontier Approach. Journal of Economics and Sustainable Development, 6 (14): 78 - 85.

20. Rufai, A.M., Salman, K.K and Salawu, M.B (2018). Input Utilization and Agricultural Labor Productivity: A Gender Analysis. Pg $55-79$ in: Shimless, et al (eds). Building a Resilent and Sustainable Agriculture in Sub-Saharan Africa.

21. Shabu, T (2013). Determination of Resource-Use Efficiency of Rice in Kaambe District of Guma Local Governement Area of Benue State, Nigeria. World Journal of Agricultural Research, 1 (6): 143 - 148.

22. Singbo, A.G and Lansink, A.O (2010). Lowland Farming System Inefficiency in Benin (West Africa): Directional Distance Function and Truncated Bootstrap Approach. Food Security, $2(4): 367-382$.

23. Tesema, T., Kebede, $T$ and Shumeta, $Z$ (2019). Economic Efficiency of Smallholder Farmers in Maize Production in Gudeya Bila District, Oromia National Regional State, Ethiopia: Parametric Approach. Journal of Applied Agricultural Economics and Policy Analysis, 2(1): $1-7$.

24. Yabi, A.J (2009). Efficiency in Rice Production: Evidence from Gogounou District in the North of Benin. Annales des Sciences Agronomiques, 12 (2): 61 - 75.

25. Yamane, T (1967). Statistics: An Introductory Analysis. 2nd Edition, New York, Harper and Row Publishers. 